\title{
A Teaching Toolbox for Understanding Urban Wetlands
}

\section{Susan Purdy}

\author{
Thompson Rivers University, Biological Sciences, 805 TRU Way, Kamloops BC CAN \\ $\mathrm{V} 2 \mathrm{C} 0 \mathrm{C} 8$ \\ (spurdy@tru.ca)
}

\begin{abstract}
There are many good reasons to use locally available urban wetlands to teach our students about important ecological processes as well as to expose them to real world issues. Wetlands are an extremely valuable ecosystem, housing extensive biodiversity, and also particularly in urban areas, important nutrient sinks. This 'three-step teaching toolbox' takes our non-majors environmental biology students through a series of labs to better understand the importance of wetlands, especially in regard to nutrient removal. We started with a $\mathrm{SimBio}^{\mathrm{TM}}$ virtual reality lab on nutrient pollution in aquatic ecosystems. Next, they performed an in-lab experiment on the effects of the addition of nutrients on algal growth using water collected from an oligotrophic lake and a eutrophic lake, to test their hypotheses on limiting nutrients. Lastly, in the third phase of this study we went out to the wetlands for extensive abiotic and biotic sampling and then back into the lab for analysis of the data and samples. Through a partnership with the City of Kamloops Nature Parks department, the data collected by our students is extremely valuable in an on-going monitoring program for the wetlands.
\end{abstract}

Keywords: wetlands ecology, teaching toolbox, hypothesis testing

Link to Original Poster File: https://doi.org/10.37590/able.v41.poster79

\section{Mission, Review Process \& Disclaimer}

The Association for Biology Laboratory Education (ABLE) was founded in 1979 to promote information exchange among university and college educators actively concerned with teaching biology in a laboratory setting. The focus of ABLE is to improve the undergraduate biology laboratory experience by promoting the development and dissemination of interesting, innovative, and reliable laboratory exercises. For more information about ABLE, please visit http://www.ableweb.org/.

Advances in Biology Laboratory Education is the peer-reviewed publication of the conference of the Association for Biology Laboratory Education. Published articles and extended abstracts are evaluated and selected by a committee prior to presentation at the conference, peer-reviewed by participants at the conference, and edited by members of the ABLE Editorial Board. Published abstracts are evaluated and selected by a committee prior to presentation at the conference.

\section{Citing This Article}

Purdy S. 2020. A teaching toolbox for understanding urban wetlands. Article 79 In: McMahon K, editor. Advances in biology laboratory education. Volume 41. Publication of the 41st Conference of the Association for Biology Laboratory Education (ABLE). https://doi.org/10.37590/able.v41.abs79

Compilation (C) 2020 by the Association for Biology Laboratory Education, ISBN 1-890444-17-0. All rights reserved. No part of this publication may be reproduced, stored in a retrieval system, or transmitted, in any form or by any means, electronic, mechanical, photocopying, recording, or otherwise, without the prior written permission of the copyright owner.

ABLE strongly encourages individuals to use the exercises in this volume in their teaching program. If this exercise is used solely at one's own institution with no intent for profit, it is excluded from the preceding copyright restriction, 
otherwise noted on the copyright notice of the individual chapter in this volume. Proper credit to this publication must be included in your laboratory outline for each use; a sample citation is given above. 